\title{
A method for small scale genomic DNA isolation from chickpea (Cicer arietinum L.) suitable for molecular marker analysis
}

\author{
Neha Joshi, Anamika Rawat, R. B. Subramanian and K. S. Rao \\ B. R. Doshi School of Biosciences, Sardar Patel Maidan, Vadtal Road, Post Box No. 39, \\ Sardar Patel University, Vallabh Vidyanagar-388120, Gujarat, India \\ neha_sjoshi@yahoo.co.in, subramanianrb@gmail.com
}

\begin{abstract}
We describe a DNA isolation procedure for chickpea (Cicer arietinum L.) which is rapid and less expensive without involving ultra centrifugation or column purification steps. DNA preparation obtained from the present study was essentially suitable for PCR analysis which is one of the key steps in crop improvement programme through marker development and genetic engineering techniques. The yield of DNA ranged from $0.595-5.550 \mu \mathrm{g} / \mathrm{ml}$ and the purity ratio was between 1.025- 2.010 indicating minimum levels of contaminating metabolites. The present protocol offers as a reliable, and consistent DNA isolation method for chickpea that yields large amount of pure \& intact DNA.
\end{abstract}

Keywords: DNA isolation, Cicer arietinum, PCR analysis.

Introduction

Chickpea (Cicer arietinum L.) is an important food legume cultivated in over 40 countries. The emergence of plant transformation and molecular marker analysis in genome studies has greatly enhanced the speed and efficiency of crop improvement and breeding programme. With the development of polymerase chain reaction (PCR) technology, molecular markers based on PCR soon found a wide application in plant genetics and breeding. A prerequisite of taking advantages of these methods is the ability to isolate genomic DNA of superior quality and quantity for analyzing through $\mathrm{PCR}$, restriction enzyme digestion and subsequent Southern blot hybridization. To fulfill this criterion, a rapid, simple and reliable DNA isolation method is highly solicited. Large variations in size, content and organization of genome and contents of metabolites have been reported in different plant species. A single DNA isolation protocol is not likely to be applicable for all plant systems (Loomis, 1974). Chemotypic heterogeneity among species may not allow optimal DNA yield with a single protocol, thus even closely related species may require different isolation protocols (Weishing et al., 1995).

The traditional DNA macro preparation method usually requires a minimum of $0.5 \mathrm{~g}$ of plant tissue, making it impractical to analyze individual plants during the early seedling stage. In addition these methods are time consuming and laborious due to their multi-step procedures. Furthermore, large amounts of hazardous reagents like $C T A B$ are incorporated during the extraction procedures. Modifications have been made for plant species like chickpea, lentil, pea, soybean and barley, which are high in polysaccharides. These modified methods are usually employed to remove polysaccharides (Lodhi et al., 1994). The isolation of good quality DNA from chickpea is complicated due to the presence of high content of phenolic compounds. During Research article CIndian Society for Education and Environment (iSee) tissue homogenization, phenolics become oxidized and irreversibly bind to the protein and nucleic acids (Loomis, 1974). This irreversible binding produces a gelatinous material, which is hard to separate from organelles and the result is that the DNA becomes unsuitable for PCR and restriction enzyme digestion analysis (Porebski, 1997). Polysaccharides are also problematic (Scott \& Playford, 1996), as acidic polysaccharides inhibit digestion of $\lambda$ DNA by certain endonucleases like Hindll (Do \& Adams, 1991) and classical 2-primer PCR amplification (Pandey et al., 1996) by inhibiting Taq DNA polymerase activity (Fang et al., 1992), whereas neutral polysaccharides are non-inhibitory (Do \& Adams, 1991; Pandey et al., 1996). In addition, polysaccharides can cause anomalous re-association kinetics of DNA sample (Merlo, 1976). They co-precipitate with DNA during alcohol precipitation to form a highly viscous solution (Do \& Adams, 1991) making the DNA unsuitable for restriction enzyme digestion and Southern blot hybridization. The DNA tends to stick to the wells of the gel during electrophoretic analysis. The contamination of polysaccharides can be overcome by increasing the volume of extraction buffer, thereby diluting the inhibitory polysaccharides (Pandey et al., 1996). However, excessive dilution makes it inconvenient for further analysis. The problem of polyphenols and polysaccharides is exacerbated if green, over matured tissue is taken rather than etiolated leaves (Sharma et al., 1996). To overcome these difficulties, we modified the available DNA isolation methods. We report on a rapid and low-cost method for relatively high-thorough put extraction of high quality DNA from young leaves of chickpea that is free of contaminants and colored pigments and can be amplified by means of PCR.

Materials and Methods

Eight varieties of chickpea namely Dahod Yellow (DY), GG-1, GG-2, GG-3, GG-4, JCP-27, JG- 62 and WR-315 Neha Joshi et al. Indian J.Sci.Technol. 
were obtained from Junagadh Agricultural University and grown at the experimental site. After acclimatization, young leaves were harvested fresh for DNA isolation. One gram of leaf tissue was transferred to pre-chilled mortar and pestle and homogenized with $5 \mathrm{ml}$ of extraction buffer comprising $250 \mathrm{mM} \mathrm{NaCl} ; 25 \mathrm{mM}$ EDTA $(\mathrm{pH}), 0.5 \%$ SDS, $200 \mathrm{mM}$ Tris- $\mathrm{HCl}, \mathrm{PVP}(0.1 \mathrm{~g} / \mathrm{g}$ of leaf tissue added while grinding), $50 \mu \mathrm{l} \beta$-mercaptoethanol (added while grinding). The ground homogenate was incubated at $65^{\circ} \mathrm{C}$ for $1 \mathrm{~h}$. Homogenate was centrifuged at $10000 \mathrm{rpm}$ for $10 \mathrm{~min}$ at $4^{\circ} \mathrm{C}$. The supernatant was collected in fresh tubes and to it equal volume of chloroform: isoamyl alcohol (24:1) was added. The tubes were gently mixed for $30 \mathrm{~min}$ to ensure maximum extraction of pigments in the chloroform layer and elimination of brownish colour in the DNA sample. The tubes were then centrifuged at $10000 \mathrm{rpm}$ for $20 \mathrm{~min}$ at $4^{\circ} \mathrm{C}$. Supernatant was carefully decanted and transferred to new tubes to which $6 \mu \mathrm{l} / \mathrm{ml}$ of RNase $(2 \mathrm{mg} / \mathrm{ml} \mathrm{stock})$ was added. The tubes were kept at $37^{\circ} \mathrm{C}$ for $1 \mathrm{~h}$. The supernatant was mixed with equal volumes of phenol:chloroform:isoamyl alcohol (25:24:1) and centrifuged at $10000 \mathrm{rpm}$ for $10 \mathrm{~min}$ at $4^{\circ} \mathrm{C}$. The aqueous layer was transferred to a new tube and re-extracted with equal volumes of chloroform and isoamyl alcohol (24:1) by centrifuging at $10000 \mathrm{rpm}$ for $10 \mathrm{~min}$ at $4^{\circ} \mathrm{C}$. Aqueous layer was collected and equal amount of chilled ethanol was added to it and kept at $-20^{\circ} \mathrm{C}$ for overnight extraction of DNA. The yield of DNA per gram of leaf tissue extracted was measured using a UV-visible spectrophotometer (Spectronic Unicam) at $260 \mathrm{~nm}$. The purity of DNA was determined by calculating the ratio of absorbance at $A_{260} / A_{280}$. DNA concentration and purity were also determined by running the samples on $0.8 \%$ agarose gel (Fig. 1). Nucleic acid concentration was calculated by the method of Sambrook et al. (1989).

SSR-PCR analysis

DNA isolated from this method was tested for its amenability by subjecting it to PCR analysis. Isolated DNA from the 8 chickpea varieties were screened by a reference kit of chickpea specific SSR markers which has been developed under the frame of generation challenge program by ICRISAT and ICARDA (Varshney et al., 2007). The sequence information and other characteristics are available from the public domain (http:/www.icrisat.org). A set of 15 SSR markers, covering different genomic locations were analyzed in this study under optimized PCR conditions. PCR amplifications were performed in 10X Taq DNA polymerase buffer (100 $\mathrm{mM}$ Tris $\mathrm{HCl}, \mathrm{pH}$ 9, $500 \mathrm{mM} \mathrm{KCl}, 1 \%(\mathrm{~V} / \mathrm{V})$ Triton X-100), $15 \mathrm{mM} \mathrm{MgCl}, 10 \mu \mathrm{M}$ dNTP, $0.24 \mu \mathrm{m}$ each of forward and reverse primer, $100 \mathrm{ng}$ of DNA and 1 unit of Taq DNA polymerase per $12.5 \mu \mathrm{l}$ of the reaction. The thermocycler (Applied Biosystems) was programmed for an initial denaturation step of $2 \mathrm{~min}$ at $95^{\circ} \mathrm{C}$ followed by 35 cycles of denaturation for $45 \mathrm{sec}$ at $95^{\circ} \mathrm{C}$, annealing at $57^{\circ} \mathrm{C}$ for $1 \mathrm{~min}$, elongation at $72^{\circ} \mathrm{C}$ for $45 \mathrm{sec}$. Final elongation was carried out at $72^{\circ} \mathrm{C}$ for 5 min with a hold temperature of $4^{\circ} \mathrm{C}$ at the end. PCR products were analyzed on $2.5 \%$ $(\mathrm{W} / \mathrm{V})$ agarose gel electrophoresis in 1X TAE buffer at 50 $\mathrm{V}$ for $3 \mathrm{~h}$ and then stained with ethidium bromide $(0.5$ $\mu \mathrm{g} / \mathrm{ml})$. Gels with amplified products were visualized and photographed under UV transilluminator. A $20 \mathrm{bp}$ and a $100 \mathrm{bp}$ DNA ladder (Bangalore Genei) were used as molecular markers to know the size of products.

Table 1. Chickpea varieties, their purity ratio \& concentration values obtained after taking absorbance at 260/280.

\begin{tabular}{|l|c|c|}
\hline \multicolumn{1}{|c|}{ Variety } & Purity ratio & Conc. $(\mu \mathrm{g} / \mu \mathrm{l})$ \\
\hline JG-62 & 2.010 & 2.060 \\
\hline GG-1 & 1.680 & 0.975 \\
\hline GG4 & 1.750 & 1.845 \\
\hline JCP-27 & 1.610 & 1.075 \\
\hline GG-2 & 1.425 & 5.550 \\
\hline GG-3 & 1.387 & 2.605 \\
\hline DY & 1.025 & 0.595 \\
\hline WR-315 & 1.030 & 0.790 \\
\hline
\end{tabular}

Fig. 1. Electrophoretic analysis of total DNA isolated from eight chickpea varieties- Lane 1-100 bp DNA ladder; Lane 2- JG-62, Lane 3- GG-1; Lane 4- GG-4; Lane 5- JCP-27, Lane 6-GG-2; Lane 7-GG-3; Lane 8-DY; Lane 9-WR-315

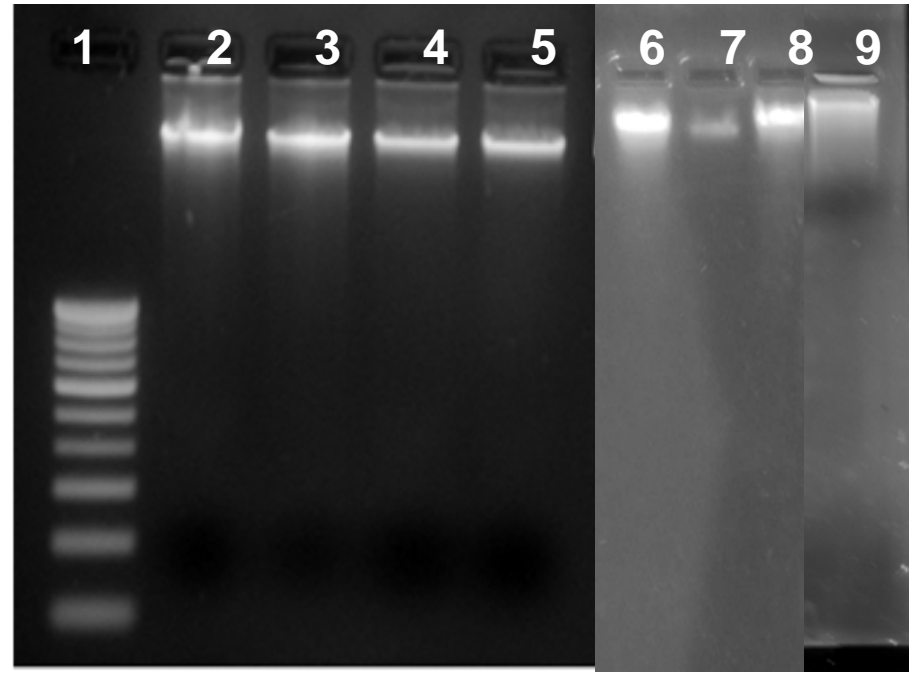

\section{Results}

The quality of genomic DNA isolated from fresh leaf tissue was evaluated by agarose gel electrophoresis of undigested genomic DNA. The resultant DNA was of acceptable quality. Fig. 1 shows the isolated DNA as intact band without any characteristic smearing. The total DNA yield (across all 8 crops) as measured by absorbance spectroscopy was in the range of 0.595 $5.550 \mathrm{\mu g} / \mathrm{ml}$ with $A_{260} / A_{280}$ ratio in the range of $1.025-$ 2.010 (Table 1). DNA quality was further tested by SSRPCR reaction which yielded strong and reliable products after amplification with 15 SSR primers. The result showed distinct amplification of genomic DNA to give reproducible polymorphic banding patterns in all the 8 genotypes of chickpea (Fig. 2).
Research article

CIndian Society for Education and Environment (iSee)
"DNA isolation from chickpea" http://www.indjst.org
Neha Joshi et al. Indian J.Sci.Technol. 
Fig. 2. Representative gel fractionation of SSR-PCR amplification products of 8 chickpea varieties using primers TA-22 (a), TA-46 (b), TR-29 (c) \& TA-200 (d).
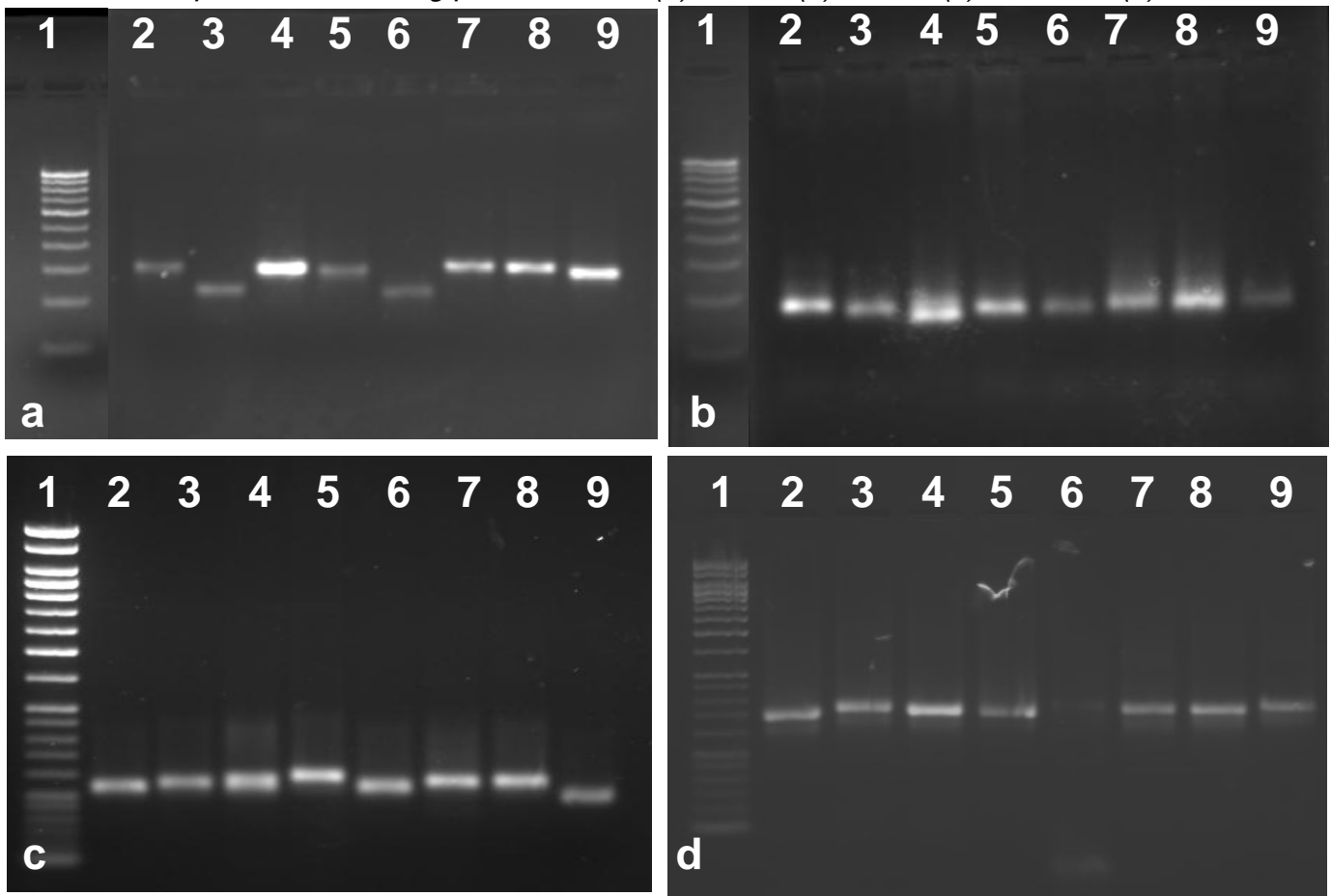

Amplification products were fractionated on a $2.5 \%$ agarose gel.

Lane 1- 100 bp DNA ladder; Lane 2- DY; Lane 3- GG-1; Lane 4- GG-2; Lane 5- GG-3; Lane 6- GG-4; Lane 7- JCP-27; Lane 8- JG-62; Lane 9- WR-315.

\section{Discussion}

The most notable problem with DNA isolation is polysaccharide contamination which inhibits restriction enzymes as well as other DNA modifying enzymes. This problem is most easily solved by using young plants which have not accumulated as much polysaccharide as older plants. In our study, the best results were obtained with plants that were 2-3 weeks old. Present procedure resulted in extraction of high quality genomic DNA from 8 varieties of Cicer arietinum. $\beta$-mercaptoethanol was found to improve extracted DNA quality (Paterson et al., 1993). Long term chloroform: isoamyl alcohol treatment ensured removal of chlorophyll and other colouring substances such as pigments, dyes etc. that hinder the quality of DNA. The popular CTAB method (Doyle \& Doyle, 1990) which focused on the removal of polyphenolics and/or polysaccharides, often neglected the importance of eliminating RNA. Many DNA isolation procedures also yielded large amounts of RNA specially $18 S$ and $28 S$ rRNA (Doyle \& Doyle, 1987). Large amounts of RNA in the sample can chelate $\mathrm{Mg}^{2+}$ and reduce yield of DNA. Several reports have indicated that the presence of RNA can suppress PCR amplification patterns in RAPD analysis (Pikart \& Villeponteau, 1993). From our study, the most inexpensive and reliable method appears to be a prolonged RNase treatment, which degraded RNA into ribonucleosides that do not contaminate the DNA preparation and yield RNA free pure DNA.

DNA isolated by this method yielded strong and reliable amplification products showing its compatibility for SSR-PCR. In the present study, out of the 15 primer pairs used, 11 were found to be polymorphic while 4 yielded monomorphic banding patterns. The polymorphic markers included TA-22 (Fig. 2a), TA-46 (Fig. 2b), TR-29 (Fig. 2c) and TA-200 (Fig. 2d). A total of 42 alleles were detected for 15 SSR loci at an average of 2.8 alleles per locus. Almost all the SSR loci consisted of tri-repeats of both adenine and thymine. In the present study, 19 out of 42 alleles were found to be 'unique'. Among the 8 varieties, maximum number of unique alleles were seen in GG2 (4 bands) and GG3 ( 3 bands). The analysis also revealed that a set of 8 SSR Ioci (CaSTMS2, CaSTMS15, TA22, TR7, TA46, TA64, TA71 \& TA72) could differentiate 7 out of 8 varieties on the basis of unique/rare alleles. The co-dominant nature of the SSR markers (TaaSH, TR7, CaSTMS15 \& TR43) aided in the detection of 'double bands' in all varieties. These 'double bands' cannot be possibly considered as non-specific amplifications, as the size ranges of the alleles were within those expected for the loci analyzed. Reproducible amplification was observed in PCR reactions in several independent extractions and replicates. It was observed these modified steps are necessary to standardize and increase the quality and quantity of genomic DNA. Thus, it is concluded that the present protocol describes a reliable, rapid, simple and consistent DNA isolation method for chickpea that yields large amount of pure, intact DNA amenable for PCR analysis as compared to previous reports without any ultra centrifugation or column purification steps (Sharma et al., 2002; Mace et al., 2003).

\section{Acknowledgements}

We thank the Pulse Research Station, Junagadh Agricultural University for providing the chickpea varieties.
Research article

CCIndian Society for Education and Environment (iSee)
"DNA isolation from chickpea" http://www.indjst.org
Neha Joshi et al. Indian J.Sci.Technol 


\section{References}

1. Do $N$ and Adams RP (1991) A simple technique of removing plant polysaccharides contaminants from DNA. Biotechniques. 10, 162-166.

2. Doyle JJ and Doyle JL (1987) A rapid DNA isolation procedure for small quantities of fresh leaf tissue. Phytochem. Bull. 19, 11-15.

3. Doyle JJ and Doyle JL (1990) Isolation of plant DNA from fresh tissue. Focus. 12, 13-15.

4. Fang G, Hammer S and Groumet R (1992) A quick and inexpensive method for removing polysaccharides from plant genomic DNA. Biofeedback. 13, 52-54.

5. Lodhi MA, Ye GN and Weeden NF (1994) A simple and efficient method for DNA extraction from grapevine cultivars and Vitis species. Plant Mol. Biol. Rep. 12, 6-13.

6. Loomis MD (1974) Overcoming problems of phenolics and quinones in the isolation of plant enzymes and organelles. Methods Enzymol. 31, 528-544.

7. Mace ES, Buhariwalla HK and Crouch JH (2003) A high-throughput DNA extraction protocol for tropical molecular breeding programs. Plant Mol. Biol. Rep. 21, 459a-459h.

8. Merlo DJ and Kemp JD (1976) Effect of polysaccharides on kinetics of DNA. Plant Physiol. 58, 1522-1526.

9. Pandey RN, Adams RP and Flournoy LE (1996) Inhibitions of random amplified poly-morphic DNAs (RAPDs) by plant polysaccharides. Plant Mol. Biol. Rep. 14, 17-22.

10.Paterson AH, Brubaker CL and Wendel JF (1993) A rapid method for extraction of cotton (Gossypium spp.) genomic DNA suitable for RFLP and PCR analysis. Plant Mol. Biol. Rep. 11, 122-127.

11.Pikart MJ and Villeponteau B (1993) Suppression of PCR amplification by high levels of RNA. Biotech.14, 24-25.

12.Porebski S, Bailey LG and Baum BR (1997) Modification of a CTAB DNA extraction protocol for plants containing high polysaccharide and polyphenol components. Plant Mol. Biol. Rep. 15, 8-15.

13.Sambrook J, Fritch EF and Maniatis T (1989) Molecular cloning: A laboratory manual. Cold Springer Harbor Laboratory Press, Cold Spring Harbor, NY.

14.Scott KD and Playford J (1996) DNA extraction technique for PCR in rain forest plant species. Biotech. 20, 974-978.

15.Sharma AD, Gill PK and Singh P (2002) DNA isolation from dry and fresh samples of polysaccharide rich plants. Plant Mol. Biol. Rep. 20, 415a- 415f.

16.Sharma KK, Lavanya M and Anjaiah V (2000) A method for isolation and purification of peanut genomic DNA suitable for analytical applications. Plant Mol. Biol. Rep. 18, 393a-393h.
Vol. 3 No. 12 (Dec 2010)

ISSN: 0974- 6846

17.Varshney RK, Horres R, Molina C, Nayak S, Jungmann $R$, Swamy $P$, Winter $P$, Jayashree $B$, Kahl $G$ and Hoisington DA (2007) Extending the repertoire of microsatellite markers for genetic linkage mapping and germplasm screening in chickpea. J. SAT Agri. Res. 5(1), 1-3.

18. Weishing K, Nybom H, Wolff K and Meyer W (1995) DNA isolation and purification. In: DNA fingerprinting in plants and fungi, CRC Press, Boca Raton, Florida, pp: 44-59. 